\title{
THE EFFECT OF GIVING CUCUMBER (Cucumis sativus) TO DECREASE HEMOGLOBIN TROMBOSITE AND IMPROVEMEN IN PRE-ECLAMMED PATIENTS AT DEWI SARTIKA HOSPITAL
}

\author{
Novia Sarmiati ${ }^{1}$, Erwin Azizi Jayadipraja ${ }^{2}$, Labanudi ${ }^{3}$ \\ ${ }^{1,2,3}$ Magister of Public Health Study Program, College of Health Sciences Mandala \\ Waluya Kendari, Southeast Sulawesi, Indonesia
}

Corresponding Author : Novia Sarmiati

Email : novia.sarmiati01@gmail.com

\section{Abstract}

Background: According to the World Health Organization (WHO) every day in 2015, around 830 women die from complications during pregnancy and child birth. Globally, maternal mortality in the world was 303,000 in 2015. The maternal mortality rate (MMR) in Indonesia based on the Indonesian Health Demographic Survey (IDHS) in 2012 was around 359 / 100,000 live births, this figure increased compared to 2007, which was around 228 / 100,000 live births. Based on Dewi Sartika General Hospital's data with preeclampsia cases for the last three years. In 2017, the number of births in 1855 who experienced preeclampsia were 305 cases. In 2018, the number of births in 1822 who experienced preeclampsia was 334 cases. In 2019, the number of deliveries in 2007 who experienced preeclampsia was 377 cases. For 2020 January to June number of deliveries695 the incidence of preeclampsia was 164 cases.

Methods: This study used a quasi-experimental method with a pre-test-post-test control group design. The population in this study was 164 preeclampsia patients from August to October 2020.

Result: The wilcoxon test showed p value was $0.0000<\alpha=0.05$ on decreased hemoglobin and increased platelets

Conclusion:There was an effect of cucumber on decreasing hemoglobin and increasing platelets in pre-eclampsia patients at DewiSartika General Hospital.

Key words: cucumber, preeclampsia, hemoglobin, platelets 


\section{INTRODUCTION}

Preeclampsia is a pregnancy-specific syndrome with decreased organ perfusion resulting in vascular vasospasm and endothelial activation(1). As much as 3.9\% of all pregnant women in the world have preeclampsia(2). One of the complications in pregnancy is preeclampsia which causes serious illness, long-term disability, and death to the mother, foetus and neonate(3).

Preeclampsia is called a "disease of theories" because there are several theories that can explain these conditions. The theories include: placental implantation theory, immunological maladaptation, genetics, endothelial dysfunction, nutrition and hormones. Recently, endothelial and placental factors are considered important in the pathogenesis of preeclampsia, but many other unknown factors have been recognized(4). In preeclampsia there is no invasion of trophoblast cells in the muscle layer of the spiral artery and surrounding matrix tissue which can result in decreased placental perfusion and continued placental hypoxia and ischemia. Ischemia in the placenta results in disruption of blood flow to the fetus(5).

Data from the Southeast Sulawesi Provincial Health Office, in 2017 the number of preeclampsia cases was $12.6 \%$. in 2018 the number of preeclampsia cases was $17.8 \%$ and in 2019 the number of preeclampsia cases was 21.3\% (Dinkes Sultra, 2019). Data from the Health Counselling Office in 2017 were $19.4 \%$ of preeclampsia cases, $17.42 \%$ of preeclampsia cases in 2018 and $21.4 \%$ of preeclampsia cases in 2019(6). Whereas for the Kendari City area, based on data in 2017, there were $24.5 \%$ of Preeclampsia cases, 19.4\% of Preeclampsia cases in 2018 and $26.1 \%$ of Preeclampsia cases in 2019 (7).

Data from Dewi Sartika General Hospital with preeclampsia cases for the last three years. In 2017, the number of births in 1855 who experienced preeclampsia were 305 cases. In 2018 the number of births in 1822 who experienced preeclampsia was 334 cases. In 2019 the number of deliveries in
2007 who experienced preeclampsia was 377 cases. For 2020 January to June number of deliveries695the incidence of preeclampsia was 164 cases. The high number of childbirth visits at Dewi Sartika General Hospital is because Dewi Sartika Hospital has a strategic location on the border of Konsel with Kendari besides that Dewi Sartika General Hospital also collaborates with 4 cities / districts for health assurance (BPJS of indonesian term) (8).

Preeclampsia cases can be caused in various diseases. The cause of preeclampsia is placental ischemia, in addition there are other factors that cause preeclampsia, namely primigravida, maternal age $<20$ years or $>35$ years, family history of preeclampsia, multiple pregnancies, diabetes and obesity (9).

Laboratory tests such as routine blood tests can help early detection of preeclampsia so that action and prevention can be taken immediately. Research(10), explained that pre-chlamydial patients experienced an increase in haemoglobin and a decrease in platelets. The increase in hemoglobin is caused by haematological abnormalities and impaired heme degradation. The presence of endothelial damage causes haematological abnormalities by leaking between the gaps in the endothelial cells, then resulting in a decrease in plasma volume intravascular leading to hemo concentration. These results are consistent with (11) who revealed that in pre-eclampsia, loss of serum protein and increased capillary endothelial permeability causes a decrease in intravascular volume. Hemo concentration will cause a state of thrombocytopenia and an increase in erythrocyte production, so that haemoglobin levels are also high.

\section{METHOD}

This study used a quasi-experimental type with a pre-test-post-test control group method design(1). The research period was conducted for 3 months starting from August to October 2020. The population in this study was 164 people, with a sample size of 


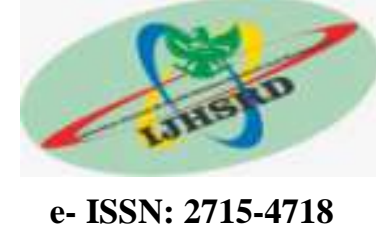

116 people in all preeclampsia patients from August to October 2020 as many as 164 people. The questionnaire was used as a data collection method(2).

\section{RESULT}

Table 1.shows that from 116 respondents, most are in the age category 3135 years as many as 59 respondents $(50.9 \%)$ and the smallest is the age category 20-25 years as many 13 respondents $(11.2 \%)$.

Table 2.Itshows from 116 respondents, most are respondents with blood pressure $150 / 90 \mathrm{mmHg}$ namely 51 respondents $(44.0 \%)$ and the smallest is the respondent with blood pressure $170 / 100 \mathrm{mmHg}$ as many as 2 respondents $(1.7 \%)$.

Table 3.Itshows that in the cucumber group before the intervention, the mean hemoglobin was $17.48 \mathrm{~g} / \mathrm{dL}$ with a standard deviation1.48, after the intervention, the mean hemoglobin decreased, namely $14.15 \mathrm{~g}$ / dL by standard 0.97 and the control group before giving the intervention mean haemoglobin ie18.04 g / dL with standard deviation 1.16, after the intervention, the mean haemoglobin decreased, namely 15.33 $\mathrm{g} / \mathrm{dL}$ by standard 0.71 , This means that the cucumber group decreased the mean hemoglobin, namely $3.33 \mathrm{~g} / \mathrm{dL}$ was higher than the control group, the decrease in mean hemoglobin was $2.71 \mathrm{~g} / \mathrm{dL}$. After testing the data analysis using the wilcoxon test $(\alpha$ 0.05 ) in the cucumber group obtained $p$ 0.000 which means there is the effect of giving cucumber (Cucumis sativus) on reducing hemoglobin in preeclampsia patientsatDewiSartika

Hospital.Whileaverage Platelets that is 218 with standard deviation 16.8, after giving the intervention there was an increase in the mean Platelets that is 261 by standard 14.7and the control group before giving the intervention mean Platelets that is 224 with standard deviation 13.1, after giving the intervention there was an increase in the mean platelets that is 257 by standard 14.8This means that the cucumber group had an average increase platelets that is 43 higher than the control group mean Platelets that is 33. After testing the data analysis using the testwilcoxon test $(\alpha 0.05)$ in the cucumber group obtained p 0.000 which means there is the effect of giving cucumber (Cucumis sativus) against increased platelets in preeclampsia patientsat DewiSartika Hospital.

Table 1

Distribution of Respondents by Age at Dewi Sartika Hospital

\begin{tabular}{c|c|c|c}
\hline No. & Age & $\mathrm{n}$ & $\%$ \\
\hline 1 & 20-25 years & 13 & 11.2 \\
2 & 26-30 Years & 21 & 18.1 \\
3 & 31-35 Years & 59 & 50.9 \\
4 & 36-40 Years & 23 & 19.8 \\
\hline \multicolumn{2}{l}{} \\
\hline
\end{tabular}


Sarmiati, N., E.A. Jayadipraja, \& Labanudi.

DOI: 10.36566/ijhsrd/Vol3.Iss1/42

https://ijhsrd.com/index.php/ijhsrd

e- ISSN: 2715-4718

Table 2

Blood Pressure Distribution of Respondents at Dewi Sartika Hospital

\begin{tabular}{c|c|c|c}
\hline No. & Blood pressure & $\mathrm{n}$ & $\%$ \\
\hline 1 & $140 / 90 \mathrm{mmHg}$ & 34 & 29.3 \\
2 & $150 / 90 \mathrm{mmHg}$ & 51 & 44.0 \\
3 & $160 / 90 \mathrm{mmHg}$ & 5 & 4,3 \\
4 & $170 / 90 \mathrm{mmHg}$ & 9 & 7,8 \\
5 & $140 / 100 \mathrm{mmHg}$ & 8 & 6.9 \\
6 & $150 / 100 \mathrm{mmHg}$ & 4 & 3,4 \\
7 & $160 / 100 \mathrm{mmHg}$ & 3 & 2,6 \\
8 & $170 / 100 \mathrm{mmHg}$ & 2 & 1.7 \\
\hline \multicolumn{2}{l}{} \\
\hline
\end{tabular}

Table 3

Influence Giving Cucumber (Cucumis sativus) Against Decrease

Haemoglobin and Increased Platelets in Preeclampsia Patients At Dewi Sartika Hospital

\begin{tabular}{|c|c|c|c|c|c|c|c|c|}
\hline \multirow{3}{*}{ Variable } & \multicolumn{2}{|c|}{ GivingCucumber } & \multirow{3}{*}{$\begin{array}{c}\text { Delta } \\
\qquad \Delta\end{array}$} & \multirow{3}{*}{$\begin{array}{c}p \\
\text { value }\end{array}$} & \multicolumn{2}{|c|}{ Control } & \multirow{3}{*}{$\begin{array}{c}\text { Delta } \\
\qquad \Delta\end{array}$} & \multirow{3}{*}{$\begin{array}{c}P \\
\text { Value }\end{array}$} \\
\hline & Pre & Post & & & Pre & Post & & \\
\hline & $\begin{array}{c}\text { Mean }+ \\
\text { SD }\end{array}$ & $\begin{array}{c}\text { Mean + } \\
\text { SD }\end{array}$ & & & $\begin{array}{c}\text { Mean + } \\
\text { SD }\end{array}$ & $\begin{array}{c}\text { Mean }+ \\
\text { SD }\end{array}$ & & \\
\hline Hemoglobin & $\begin{array}{c}17.48+ \\
1.48\end{array}$ & $\begin{array}{c}14.15+ \\
0.97\end{array}$ & 3.33 & 0,000 & $\begin{array}{l}18.04 \\
+1.16\end{array}$ & $\begin{array}{c}15.33+ \\
0.71\end{array}$ & 2.71 & 0,000 \\
\hline Platelets & $\begin{array}{c}218+ \\
16.8\end{array}$ & $\begin{array}{c}261+ \\
14.7\end{array}$ & 43 & 0,000 & $224+13.1$ & $\begin{array}{c}257+ \\
14.8\end{array}$ & 33 & 0,000 \\
\hline
\end{tabular}

Table 4

Influence Giving Cucumber (Cucumis sativus) Against Decrease Haemoglobin in Preeclampsia Patients at Dewi Sartika Hospital (Anova test)

\begin{tabular}{c|c|c|c}
\hline Group & Homogeneity & $p$ value & Mean \\
\hline Cucumber (Cucumis sativus) & 0.622 & 0,000 & 14,152 \\
Control & & & 15,338 \\
\hline
\end{tabular}

\section{DISCUSSION}

There is an effect of giving cucumber to decrease hemoglobin in preeclampsia patients.

The results of data analysis using the test wilcoxon test $(\alpha=0.05)$ in the cucumber group obtained $p=0.000$ which means there is the effect of giving cucumber (Cucumis sativus) on reducing hemoglobin in preeclampsia patients at Dewi Sartika Hospital.

Empirically there is a significant effect of giving cucumber juice on reducing blood pressure and improving haemoglobin, this is possible because cucumbers contain potassium, magnesium and phosphorus, 
where these minerals can effectively treat hypertension (3).

Potassium content has been widely studied in relation to blood pressure regulation. States several mechanisms by which potassium can lower blood pressure as follows potassium can lower blood pressure by causing a vasodilating effect, causing a decrease in total peripheral retention and increasing cardiac output. Consumption of a lot of potassium will increase the concentration in the intracellular fluid so that it tends to draw fluid from the extracellular part and reduce blood pressure (4).

The results showed giving Cucumber (Cucumis sativus) experienced an improvement in the mean haemoglobin in the cucumber group before the intervention was given the mean haemoglobin was 17.48 $\mathrm{g} / \mathrm{dL}$ with a standard deviation of 1.48 , after the intervention there was a decrease in the mean haemoglobin which was $14.15 \mathrm{~g} / \mathrm{dL}$ with a standard of 0,97 and the control group before giving the intervention the mean haemoglobin was $18.04 \mathrm{~g} / \mathrm{dL}$ with a standard deviation of 1.16, after the intervention there was a decrease in the mean haemoglobin which was $15.33 \mathrm{~g} / \mathrm{dL}$ with a standard of 0.71 , meaning that the cucumber group had a decrease in mean haemoglobin. namely $3.33 \mathrm{~g} / \mathrm{dL}$, which was higher than the control group, the decrease in mean haemoglobin was $2.71 \mathrm{~g} / \mathrm{dL}$.

The results of this study are in line with research(5)explain cucumber juice which can affect blood pressure. This occurs because the content in cucumbers, namely potassium, magnesium, and phosphorus, causes inhibition of the Renin Angiotensin System and will also cause vasodilatation of peripheral blood vessels. Research(6)explain Consumption of $150 \mathrm{ml}$ of cucumber juice for 7 days can significantly reduce systolic and diastolic blood pressure in hypertensive men and women.
There is an effect of giving cucumber on the increase in platelets in Preeclampsia patients at Dewi Sartika Hospital.

The results of data analysis using the Wilcoxon test $(\alpha=0.05)$ in the cucumber group obtained $p=0,000$ which means that there is an effect of giving cucumber (Cucumis sativus) on the increase in platelets in preeclampsia patients at RSU Dewi Sartika.

Platelets are small fragments that come from the cytoplasm. Disc-shaped and contains granules. There are 250,000400,000 pieces of blood in every $\mathrm{mm} 3$ of human blood. The life span of platelets is 10 days (7). Platelets are produced in the bone marrow by fragmentation of the cytoplasm of megakaryocytic. Megakaryocytemegakaryoblast precursors arise by the process of differentiation from hemopoietic stem cells. Megakaryocyte maturation by endomitotic nucleus replication process. Cytoplasmic volume can increase when the nucleus is doubled. The cytoplasm will then become granular and then the platelets are released. Each megakaryocytic is capable of producing 4000 platelets. The time interval from stem cell differentiation to platelet production is about 10 days in humans (8).

The results showed that the administration of cucumber (Cucumis sativus) experienced an improvement in the trambocyte rate of the respondents, which was proven before the intervention, the mean of platelets was 218 with a standard deviation of 16.8, after the intervention there was an increase in the mean of platelets, namely 261 with a standard of 14.7 and the control group before giving intervention that is 224 with a standard deviation of 13.1, after the intervention, there was an increase in the mean platelet count, namely 257 with a standard of 14.8 , meaning that the cucumber group had an increase in the mean platelet count, which was 43 higher than the control group with a mean of 33 .

The results of research conducted by (9), proved that consuming a combination of pumpkin can effectively reduce blood 
pressure in patients with hypertension and improve trambocytes. And in accordance with research (10), it proves that there is an effect of giving pumpkin stew on trambocytes in people with hypertension.

\section{CONCLUSION}

There is an effect of cucumber administration on decreasing haemoglobin and increasing platelets in preeclampsia patients at Dewi Sartika General Hospital. The hospital is expected to be able to use this therapy as a non-pharmacological basic therapy to reduce haemoglobin and increase platelets in preeclampsia patients.

\section{REFERENCES}

1. Yuliana M, Jatmiko SW. Differences in Hemoglobin, Hematocrit and Platelet Levels between Preeclamptic and NonPreeclamptic Patients: Muhammadiyah University of Surakarta; 2019.

2. Siska S. The Relationship between Nutritional Status and Soil Transmitted Helminth Infection with Ferritin and Hemoglobin Levels for Pregnant Women Supplemented with Iron 90 Tablets in the Work Area of Puskesmas Lubuk Buaya Padang City 2015: ANDALAS UNIVERSITY; 2017.

3. Bastian MD, Rahfiludin Z, Mawarni A. Risk Factors Cause of Anemia Incidence in Pregnant Women at Kedawung Public Health Center, Cirebon Regency, 2015: DIPONEGORO

UNIVERSITY SEMARANG; 2016.

4. Poppy S. Overview of Perinatal Outcomes in Preeclampsia-Eclampsia Mothers at Dr. M. Djamil Padang: Andalas University; 2016.

5. Zahra F. Relationship between preeclampsia and low birth weight in Bengkalis Hospital. THESIS-2014. 2020.

6. Southeast Sulawesi Health Office. Health Profile. Southeast Sulawesi2019.
7. Kendari City Health Office. Health Profile 2019.

8. Dewi Sartika Hospital. Preeclampsia Case Data. Southeast Sulawesi2020.

9. Wagiyo $N$, Kp $S$, Kep $M$, Mat $S$, Putrono SK. Antenatal, Intranatal and Newborn Nursing Care Physiology and Pathology: Publisher Andi; 2016.

10. Tiaranissa A, WB SC, Sriwahyuni E. Profile of Hemoglobin Levels in Severe Pre-Eclamptic Women Compared to Normal Pregnant Women. FKUB Health Magazine. 2016; 1 (3): 171-7.

11. Anasari T. The Effect of Hemoglobin and Hematocrit Levels on Eclampsia in Pregnant Women with Severe PreEclampsia at Rsud Margono Soekadjo Purwokerto in 2013. Midwife Prada: Journal of Midwifery Publication Akbid YLPP Purwokerto. 2015; 6 (1).

12. Mackey A, Gass SM. Second language research: Methodology and design: Routledge; 2015.

13. Sugiyono. Nonparametric Statistics for Research. 2015.

14. Anggraeny $\mathrm{O}$, Ariestiningsih $\mathrm{AD}$. Preconception Nutrition, Pregnant and Breastfeeding Women: Universitas Brawijaya Press; 2017.

15. Prakoso Imammudin $\mathrm{W}$, Soviana $\mathrm{E}, \mathrm{Gz}$ S, Gizi M. Relationship between Potassium Intake and Blood Pressure in the Elderly at Ngudi Waras Elderly Posyandu in Blulukan Village, Colomadu District, Karanganyar Regency: Muhammadiyah University of Surakarta; 2016.

16. Tjiptaningrum A. Benefits of Cucumber Juice (Cucumis sativus L.) as Therapy for Hypertension. Majority Journal. 2016; 5 (1): 112-6.

17. Lebalado LP, Mulyati T. Effect of Cucumber Juice (Cucumis sativus L.) on Systolic and Diastolic Blood Pressure in Patients with Hypertension: Diponegoro University; 2014.

18. Hendrayati TD. The Effect of Centella asiatica (L.) Urban Leaf Decoction on the Number of Blood Pieces (Platelets) 
Sarmiati, N., E.A. Jayadipraja, \& Labanudi.

DOI: 10.36566/ijhsrd/Vol3.Iss1/42

https://ijhsrd.com/index.php/ijhsrd

in Mice (Mus Musculus L.) and Their Use as Popular Scientific Work. 2015.

19. Al-Qaim FF, Abdullah MP, Othman MR, Mussa ZH, Zakaria Z, Latip J, et al. Investigation of the environmental transport of human pharmaceuticals to surface water: A case study of persistence of pharmaceuticals in effluent of sewage treatment plants and hospitals in Malaysia. Journal of the Brazilian Chemical Society. 2015; 26 (6): 1124-35.

20. Budiana N. Miracle fruit spilling disease: Group Self-Help Spreader; 2013.

21. Rusiani H, Pujianto A. Description of Types and Frequency of Food Consumption in Elderly with Hypertension: Faculty of Medicine; 2017. 